\title{
Synthesis of antipodal $\beta$-trisubstituted meso-tetraphenylporphyrins and the crystal structure of hexaphenylporphinatozinc(II) bispyridinate complex
}

\author{
BHYRAPPA PUTTAIAH ${ }^{\mathrm{a}, *}$ and VELKANNAN VEERAPANDIAN ${ }^{\mathrm{a}, \mathrm{b}}$ \\ a Department of Chemistry, Indian Institute of Technology Madras, Chennai 600 036, Tamil Nadu, India \\ ${ }^{\mathrm{b}}$ Present address: Department of Chemistry, Thiagarajar College of Engineering, Madurai 625015 , \\ Tamil Nadu, India \\ e-mail: byra@iitm.ac.in
}

MS received 4 September 2014; revised 3 November 2014; accepted 4 November 2014

\begin{abstract}
A series of antipodal $\beta$-trisubstituted meso-tetraphenylporphyrins, $\mathrm{H}_{2} \mathrm{TPP}(\mathrm{R})_{3}(\mathrm{R}=\mathrm{CH} 3, \mathrm{Ph}, \mathrm{PE}$, and $2^{\prime}$-thienyl) derivatives and their metal $(\mathrm{Cu}$ (II) and $\mathrm{Zn}(\mathrm{II}))$ complexes were synthesised and characterised by electronic absorption, ${ }^{1} \mathrm{H}$ NMR spectroscopy and mass spectrometry. The magnitude of the red-shift in absorption bands in these free-base porphyrins depend on the nature of the substituent and follow the general trend: $\mathrm{PE}>2^{\prime}$-thienyl $>\mathrm{Br}>\mathrm{Ph}>\mathrm{CH}_{3}$. Synthesis, characterisation and crystal structure of 2,5,10,12,15,20hexaphenylporphinato zinc(II) bispyridinate, $\mathrm{ZnTPP}(\mathrm{Ph})_{2}(\mathrm{Py})_{2}$ complex is also reported. It shows planar geometry of the porphyrin ring with two $\beta$-phenyls located at the antipodal 2,12-pyrrole positions. The two axially coordinated pyridine ring planes are oriented almost parallel to each other and they are in staggered conformation relative to opposite pyrrolic nitrogens. The normal-coordinate structural decomposition analysis of the $\mathrm{ZnTPP}(\mathrm{Ph})_{2}(\mathrm{Py})_{2}$ complex revealed slight wave distortion of the macrocycle.
\end{abstract}

Keywords. Synthesis; $\beta$-pyrrole trisubstituted porphyrins; substituted porphyrins; metalloporphyrins; hexaphenylporphyrin; crystal structure.

\section{Introduction}

Synthesis of functionalised porphyrins and metalloporphyrins are of remarkable interest because of their use as model compounds of biological significance. ${ }^{1,2}$ The highly substituted tetrarylporphyrins exhibited distorted structures owing to the repulsive interaction among the substituents. These porphyrins were employed as model compounds of non-planar distortions of hemes in heme proteins. ${ }^{3,4}$ The introduction of appropriate substituents at the periphery of the porphyrin macrocycle provide altered properties and have been found to be potentially useful in a variety of material applications. ${ }^{5}$ Many meso-tetraarylporphyrins and their metal complexes find use in applications such as supramolecular network-solids ${ }^{6,7}$ catalysts, ${ }^{8-10}$ liquid crystals, ${ }^{5}$ nonlinear optics, ${ }^{11}$ dye-sensitised solar cells ${ }^{12}$ and others. ${ }^{2}$

The presence of electron donating or withdrawing groups at the $\beta$-pyrrole positions of the porphyrin ring induces significant changes in optical absorption, electrochemical redox and stereochemical properties., ${ }^{2,13-15}$ Notably, the MTPPs with fewer (1-4) or more brominated porphyrins have been useful precursors to the

\footnotetext{
*For correspondence
}

synthesis of a variety of other porphyrins that are preparatively difficult. ${ }^{16-28}$ The reaction of stoichiometric amounts of NBS with $\mathrm{H}_{2} \mathrm{TPP}$ in $\mathrm{CHCl}_{3}$ at ambient conditions produced regioselective product, $\mathrm{H}_{2} \mathrm{TPPBr}_{4} \cdot{ }^{29,30}$ It is a useful precursor in the preparation of other tetra-substituted MTPPs with interesting physicochemical properties. ${ }^{21,23,28}$ The regioselective synthesis of $\beta$-pyrrole brominated $\mathrm{H}_{2} \mathrm{TPPBr}_{\mathrm{n}}$ ( $\mathrm{n}=$ 1-3) are difficult to synthesise which often lead to mixture of products. In our previous work, we reported the synthesis and separation of dibromo and tribromo- $\mathrm{H}_{2}$ TPP derivatives. ${ }^{22}$ Further, crystal structure of the $\mathrm{ZnTPP}(\mathrm{Ph})_{3}$ (1,4-dioxane) complex showed antipodal $\beta$-pyrrole substitution of phenyl groups. ${ }^{22}$ Although, the preparation of $\beta$-dibromo- $\mathrm{H}_{2}$ TPP from N-bromosuccinimide induced bromination of $\mathrm{H}_{2} \mathrm{TPP}$ is reported in the literature,,$^{22,31-35}$ the regioselectivity has remained largely unexamined. Crystal structure of the $\mathrm{H}_{2} \mathrm{TPPBr}_{2}$ showed antipodal distribution of bromo groups with disorder over all the four pyrrole rings. ${ }^{31}$ The regioselective synthesis of 2,3-dibromo$\mathrm{H}_{2}$ TPP was achieved by bromination of $\mathrm{H}_{2} \mathrm{TPP}\left(\mathrm{NO}_{2}\right)$ followed by denitration reaction. ${ }^{36}$

In the present work, we report the synthesis and characterisation of a series of unsymmetrically 


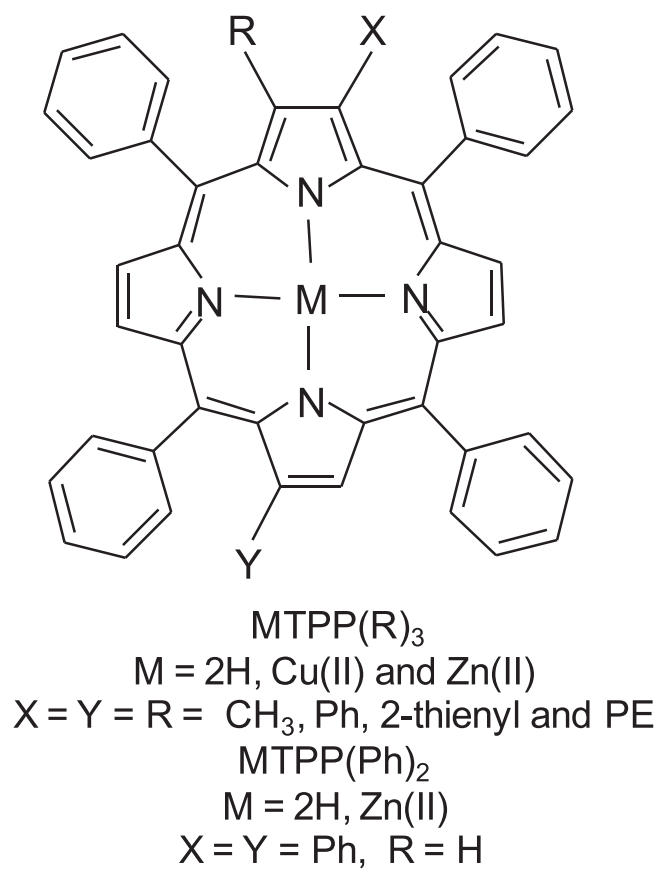

Figure 1. Chemical structures of $\beta$-trisubstituted MTPPs.

$\beta$-trisubstituted $\operatorname{MTPP}(\mathrm{R})_{3}$ derivatives (figure 1). Such unsymmetrically substituted porphyrins could be useful in non-linear optical applications. Furthermore, to determine the distribution of bromo groups in $\mathrm{H}_{2} \mathrm{TPPBr}_{2}$, the diphenyl- $\mathrm{H}_{2} \mathrm{TPP}$ and its $\mathrm{Zn}$ (II) complex were synthesised and characterised. Single crystal XRD analysis of $\mathrm{ZnTPP}(\mathrm{Ph})_{2}(\mathrm{Py})_{2}$ complex showed interesting structural features.

\section{Experimental}

\subsection{Materials}

5,10,15,20-tetraphenylporphyrin, $\mathrm{H}_{2} \mathrm{TPP}$ was prepared using reported procedure. ${ }^{37}$ The brominated precursor porphyrin, $\mathrm{H}_{2} \mathrm{TPPBr}_{\mathrm{n}}(\mathrm{n}=2$ and 3$)$ were synthesised by literature method. ${ }^{22}$ All the solvents employed in this study were of analytical grade and distilled prior to use. Propionic acid, benzaldehyde, pyrrole and Nbromosuccinimide were procured from Sigma-Aldrich (India). N-bromosuccinimide (NBS) was recrystallised from hot water and dried at $70^{\circ} \mathrm{C}$ for $12 \mathrm{~h}$ under vacuum (8.0 mbar) before use. $\mathrm{CDCl}_{3}$, benzene- $d_{6}$, DMSO- $d_{6}$, superbase $\quad(2,8,9$-triisobutyl-2,5,8,9-tetraaza-1-phosphabicyclo[3.3.3] undecane), phenylboronic acid, methylboronic acid, tributyl(2-thienyl)tin, $(\mathrm{Bu})_{3} \mathrm{Sn}(2-$ thienyl), tributyl(phenylethynyl)tin, $(\mathrm{Bu})_{3} \mathrm{Sn}(\mathrm{PE})$ and tetrakis(triphenylphosphine) palladium $(0)$ were purchased from Sigma-Aldrich (India) and used as received. Metal acetates, copper(II) acetate monohydrate and zinc(II) acetate dihydrate were procured from SRL (India) and used without further purification. Silica gel (100-200 mesh) for column chromatography were purchased from Rankem (India) and used as such. Precoated aluminum plates with silica gel for chromatography were purchased from E. Merck (Germany) and used as such.

\subsection{Instrumentation and methods}

Electronic absorption spectra of porphyrins were recorded on a JASCO V-550 model UV-Visible spectrophotometer using a pair of quartz cells of $1 \mathrm{~cm}$ path length in $\mathrm{CH}_{2} \mathrm{Cl}_{2}$ at room temperature. ${ }^{1} \mathrm{H}$ NMR spectra of porphyrins were recorded on a Bruker Avance $400 \mathrm{MHz}$ FT-NMR spectrometer in $\mathrm{CDCl}_{3}$, DMSO$d_{6}$ and benzene- $d_{6}$ using tetramethylsilane as an internal reference at $298 \mathrm{~K}$. The mass spectra of the porphyrins were carried out on an electro-spray ionization (ESI) mass spectrometer model Micromass Q-TOF micro ${ }^{\mathrm{TM}}$ in $\mathrm{CH}_{2} \mathrm{Cl}_{2}$ solvent of the porphyrin containing $5 \%$ formic acid. The metalloporphyrins were analyzed by matrix assisted laser desorption time-of-flight (MALDI-TOF) on a Voyager DE-PRO model mass spectrometer using $\alpha$-cyano-4-hydroxycinnamic acid as the matrix under positive ion mode condition. Elemental analysis of the samples was performed on a Perkin Elmer CHNO/S analyzer model 2400 series. Single crystal X-ray diffraction data collection was performed at $173 \mathrm{~K}$ on a Bruker Apex-II CCD diffractometer equipped with a liquid nitrogen cryostat.

SIR92 (WINGX) program was used to solve the structure by direct methods. ${ }^{38}$ The structure was performed on $\mathrm{F}^{2}$ using SHELXL97 software ${ }^{39}$ (Sheldrick, 1997). Structure was refined using full matrix least squares technique. The ORTEPs were generated using ORTEP- $3^{40}$ program and intermolecular interactions were calculated using Platon program. ${ }^{41}$ Single crystals of $\mathrm{ZnTPP}(\mathrm{Ph})_{2}(\mathrm{Py})_{2}, \mathbf{1}$ were grown by slow diffusion of vapours of hexane to a saturated solution of the porphyrin in 1,2-dichloroethane containing few drops of distilled pyridine over a period of week.

Crystallographic information file of $\mathrm{ZnTPP}(\mathrm{Ph})_{2}$ $(\mathrm{Py})_{2}$ structure, 1 has been deposited to the Cambridge Crystallographic Data Centre as supplementary material with the publication number CCDC 737939.

\subsection{Synthesis of $\mathrm{H}_{2} \mathrm{TPP}(\mathrm{R})_{3}\left(\mathrm{R}=\mathrm{CH}_{3}\right.$ and $\left.\mathrm{Ph}\right)$ derivatives and their metal $(\mathrm{Cu}(\mathrm{II})$ and $\mathrm{Zn}(\mathrm{II}))$ complexes}

$\mathrm{H}_{2} \mathrm{TPP}\left(\mathrm{CH}_{3}\right)_{3}$ and $\mathrm{H}_{2} \mathrm{TPP}(\mathrm{Ph})_{3}$ were prepared using reported procedures ${ }^{20}$ using six equivalent of $\mathrm{RB}(\mathrm{OH})_{2}$ 
( $\mathrm{R}=\mathrm{CH}_{3}$ or $\mathrm{Ph}$ ). The yield of $\mathrm{H}_{2} \mathrm{TPP}\left(\mathrm{CH}_{3}\right)_{3}$ and $\mathrm{H}_{2} \mathrm{TPP}(\mathrm{Ph})_{3}$ were found to be $45 \%$ and $80 \%$, respectively. The $\operatorname{MTPP}\left(\mathrm{CH}_{3}\right)_{3}(\mathrm{M}=\mathrm{Cu}$ (II) and $\mathrm{Zn}(\mathrm{II}))$ were prepared using conventional reported procedure in almost quantitative yields. $\mathbf{H}_{2} \mathbf{T P P}\left(\mathbf{C H}_{3}\right)_{3}:{ }^{1} \mathrm{H}$ NMR in $\mathrm{CDCl}_{3} \delta \mathrm{ppm}, 8.65(\mathrm{~d}, 1 \mathrm{H}, J=4.4 \mathrm{~Hz}, \beta-$ pyrrole-H), $8.61(\mathrm{~s}, 1 \mathrm{H}, \beta$-pyrrole- $\mathrm{H}), 8.57(\mathrm{~d}, 1 \mathrm{H}$, $J=4.8 \mathrm{~Hz}, \beta$-pyrrole-H), 8.55, $8.53(\mathrm{ABq}, 2 \mathrm{H}, \beta$ pyrrole- $\mathrm{H}), 8.20(\mathrm{~m}, 2 \mathrm{H}, o-\mathrm{Ph}-\mathrm{H}), 8.08(\mathrm{~m}, 6 \mathrm{H}, o-$ $\mathrm{Ph}-\mathrm{H}), 7.72(\mathrm{~m}, 12 \mathrm{H}, m$ and $p-\mathrm{Ph}-\mathrm{H}), 2.59$ (s, 3H), $2.46(\mathrm{~s}, 3 \mathrm{H}), 2.45\left(\mathrm{~s}, 3 \mathrm{H}, \mathrm{CH}_{3}-\mathrm{H}\right),-2.65(\mathrm{~s}, 1 \mathrm{H}, \mathrm{NH})$, $-2.95(\mathrm{~s}, 1 \mathrm{H}, \mathrm{NH})$. HR ESI MS calcd. for $\mathrm{C}_{47} \mathrm{H}_{36} \mathrm{~N}_{4}$ $[\mathrm{M}+\mathrm{H}]^{+}: 657.3018$ (found: 657.3030). $\mathbf{C u T P P}\left(\mathbf{C H}_{3}\right)_{3}$ : MALDI-TOF MS calcd. for $\mathrm{CuC}_{47} \mathrm{H}_{34} \mathrm{~N}_{4}: 717.207$ (found 718.36). $\mathbf{Z n T P P}\left(\mathbf{C H}_{3}\right)_{3}:{ }^{1} \mathrm{H}$ NMR $(400 \mathrm{MHz})$ in $\mathrm{CDCl}_{3}: 8.84(\mathrm{~d}, 1 \mathrm{H}, J=4.8 \mathrm{~Hz}, \beta$-pyrrole-H), 8.74 (d, $1 \mathrm{H}, J=4.8 \mathrm{~Hz}, \beta$-pyrrole-H), 8.68 (m, $2 \mathrm{H}, \beta$-pyrrole$\mathrm{H}), 8.61(\mathrm{~s}, 1 \mathrm{H}, \beta$-pyrrole-H), $8.19(\mathrm{~d}, 2 \mathrm{H}, J=7.2$ $\mathrm{Hz}, o-\mathrm{Ph}-\mathrm{H}), 8.07$ (m, 6H, o-Ph-H), $7.73(\mathrm{~m}, 12 \mathrm{H}, m$ and $p-\mathrm{Ph}-\mathrm{H}), 2.55\left(\mathrm{~s}, 3 \mathrm{H}, \mathrm{CH}_{3}-\mathrm{H}\right), 2.41\left(\mathrm{~s}, 6 \mathrm{H}, \mathrm{CH}_{3}-\right.$ H). MALDI-TOF MS calcd. for $\mathrm{ZnC}_{47} \mathrm{H}_{34} \mathrm{~N}_{4}$ : 718.207 (found: 720.06). $\mathrm{CuTPP}(\mathrm{Ph})_{3}$ and $\mathrm{ZnTPP}(\mathrm{Ph})_{3}$ were isolated in almost quantitative yields. $\mathbf{H}_{2} \mathbf{T P P}(\mathbf{P h})_{3} \cdot{ }^{1} \mathrm{H}$ NMR in $\mathrm{CDCl}_{3}: \delta_{\mathrm{H}}(\mathrm{ppm}), 8.70(\mathrm{~s}, 1 \mathrm{H}, \beta$-pyrrole-H), $8.66(\mathrm{~d}, 1 \mathrm{H}, J=4.8 \mathrm{~Hz}, \beta$-pyrrole-H), $8.52(\mathrm{~d}, 2 \mathrm{H}$, $J=4.8 \mathrm{~Hz}, \beta$-pyrrole-H), $8.42(\mathrm{~d}, 1 \mathrm{H}, J=4.8 \mathrm{~Hz}$, $\beta$-pyrrole-H), 8.25 (m, 2H, meso-o-Ph-H), 7.95 (d, 2H, $J=6.8 \mathrm{~Hz}$, meso-o-Ph-H), $7.83(\mathrm{~d}, 4 \mathrm{H}, J=7.2$ $\mathrm{Hz}$, meso-o-Ph-H), $7.74(\mathrm{~m}, 3 \mathrm{H}$, meso-m and $p-\mathrm{Ph}-$ $\mathrm{H}), 7.36(\mathrm{~m}, 2 \mathrm{H}, \beta-\mathrm{Ph}-\mathrm{H}), 7.20(\mathrm{~m}, 12 \mathrm{H}, m \& p-\mathrm{Ph}-$ $\mathrm{H} \& \beta-\mathrm{Ph}-\mathrm{H}), 6.95(\mathrm{~d}, 4 \mathrm{H}, J=7.2 \mathrm{~Hz}, \beta-\mathrm{Ph}-\mathrm{H})$, $6.88(\mathrm{~m}, 6 \mathrm{H}, \beta-\mathrm{Ph}-\mathrm{H}),-2.22(\mathrm{~s}, 2 \mathrm{H}, \mathrm{NH})$. HR ESIMS calcd. for $\mathrm{C}_{62} \mathrm{H}_{42} \mathrm{~N}_{4}[\mathrm{M}+\mathrm{H}]^{+}: 843.3487$ (found: 843.3486). CuTPP(Ph) $)_{3}$ : MALDI-TOF MS calculated for $\mathrm{CuC}_{62} \mathrm{H}_{40} \mathrm{~N}_{4}$ : 903.254 (found: 902.9). $\mathbf{Z n T P P}(\mathbf{P h})_{3}$ : ${ }^{1} \mathrm{H}$ NMR in $\mathrm{CDCl}_{3}: 8.82(\mathrm{~m}, 2 \mathrm{H}, \beta$-pyrrole- $\mathrm{H}), 8.67(\mathrm{~d}$, $1 \mathrm{H}, J=4.8 \mathrm{~Hz}, \beta$-pyrrole-H), 8.63 (d, $1 \mathrm{H}, J=4.4$ $\mathrm{Hz}, \beta$-pyrrole-H), 8.54 (d, $1 \mathrm{H}, J=4.8 \mathrm{~Hz}, \beta$-pyrrole$\mathrm{H}), 8.22(\mathrm{~m}, 2 \mathrm{H}$, meso-o-Ph-H), $7.88(\mathrm{~m}, 2 \mathrm{H}$, mesoo-Ph-H), 7.77 (m, 4H, meso-o-Ph-H), 7.71 (m, 3H, $\beta$ $\mathrm{Ph}-\mathrm{H}), 7.36$ (m, 2H, $\beta$-Ph-H), 7.18 (m, 12H, meso- $m$ $\& p-\mathrm{Ph}$ and $\beta-\mathrm{Ph}-\mathrm{H}), 6.98(\mathrm{~m}, 4 \mathrm{H}, \beta-\mathrm{Ph}-\mathrm{H}), 6.87(\mathrm{~m}$, $6 \mathrm{H}, \beta$-Ph-H). MALDI-TOF MS calcd. for $\mathrm{ZnC}_{62} \mathrm{H}_{40} \mathrm{~N}_{4}$ : 904.254 (found: 905.5 ).

2.4 Synthesis of 2,3,12-triphenylethynyl-5,10,15,20tetraphenylporphyrin, $\mathrm{H}_{2} \mathrm{TPP}(\mathrm{PE})_{3}$ and its metal $(\mathrm{Cu}(\mathrm{II})$ and $\mathrm{Zn}(\mathrm{II}))$ complexes

$\mathrm{H}_{2} \mathrm{TPPBr}_{3}(0.12 \mathrm{~g}, 0.15 \mathrm{mmol})$ and $\mathrm{Pd}\left(\mathrm{PPh}_{3}\right)_{4}(0.04 \mathrm{~g}$, $0.036 \mathrm{mmol}$ ) were dissolved in $20 \mathrm{~mL}$ of 1,4 -dioxane and allowed to stir at room temperature. To this solution, $(\mathrm{Bu})_{3} \mathrm{Sn}(\mathrm{PE})(0.32 \mathrm{ml}, 0.84 \mathrm{mmol})$ was added in $10 \mathrm{~mL}$ dioxane dropwise over a period of $15 \mathrm{~min}$. Then, the resultant mixture was stirred and refluxed for $3 \mathrm{~h}$. At the end of this period, the reaction mixture was rotary evaporated to dryness. The crude product was redissolved in $\mathrm{CHCl}_{3}$ and purified through silica gel column chromatography using $\mathrm{CHCl}_{3}$ as the eluant. The purified product was dried at $85^{\circ} \mathrm{C}$ for $6 \mathrm{~h}$ under vacuum $(8 \mathrm{mbar})$. Yield of the product: $0.1 \mathrm{~g}$ (77\%). $\mathbf{H}_{2} \mathbf{T P P}(\mathbf{P E})_{3}:{ }^{1} \mathrm{H}$ NMR $(400 \mathrm{MHz})$ in $\mathrm{CDCl}_{3}$ : $8.97(\mathrm{~s}, 1 \mathrm{H}, \beta$-pyrrole-H), $8.84(\mathrm{~d}, 1 \mathrm{H}, J=4.8$ $\mathrm{Hz}, \beta$-pyrrole-H), $8.76(\mathrm{~d}, 1 \mathrm{H}, J=5.2 \mathrm{~Hz}, \beta$ pyrrole-H), $8.69(\mathrm{~d}, 2 \mathrm{H}, J=5.4 \mathrm{~Hz}, \beta$-pyrrole$\mathrm{H}), 8.26(\mathrm{~m}, 8 \mathrm{H}$, meso-o-Ph-H), $7.72(\mathrm{~m}, 12 \mathrm{H}$, meso$m$ and $p-\mathrm{Ph}-\mathrm{H}), 7.33(\mathrm{~m}, 15 \mathrm{H}, \beta-\mathrm{PE}-\mathrm{H}),-2.64(\mathrm{~s}$, $2 \mathrm{H}, \mathrm{NH}) .{ }^{13} \mathrm{C} \mathrm{NMR}(125 \mathrm{MHz})$ in $\mathrm{CDCl}_{3:} \delta 141.7$, $141.4,141.2,140.8,134.8,134.8,134.7,134.5,132.1$, 132.0, 129.4, 128.8, 128.7, 128.5, 128.0, 127.9, 127.8, 127.0, 127.0, 126.9, 126.8, 124.0, 123.8. 120.4, 120.2, 120.1, 119.8, 104.7, 104.7, 99.1, 86.2, 86.0. HR ESIMS calcd. for $\mathrm{C}_{68} \mathrm{H}_{43} \mathrm{~N}_{4}(\mathrm{M}+\mathrm{H}]^{+}: 915.3488$ (found 915.3483). CuTPP(PE) $)_{3}$ : MALDI-TOF MS calcd. for $\mathrm{CuC}_{68} \mathrm{H}_{40} \mathrm{~N}_{4}$ : 975.254 (found 975.86). ZnTPP(PE) $)_{3}$ : ${ }^{1} \mathrm{H} \mathrm{NMR}(400 \mathrm{MHz})$ in $\mathrm{CDCl}_{3}: \delta 9.15$ (s, $1 \mathrm{H}, \beta$-pyrrole$\mathrm{H}), 8.84(\mathrm{~d}, 1 \mathrm{H}, J=4.8 \mathrm{~Hz}, \beta$-pyrrole-H), $8.76(\mathrm{~d}$, $1 \mathrm{H}, J=4.8 \mathrm{~Hz}, \beta$-pyrrole-H), 8.69 (m, $2 \mathrm{H}, \beta$-pyrrole$\mathrm{H}), 8.18(\mathrm{~m}, 8 \mathrm{H}$, meso-o- $\mathrm{Ph}-\mathrm{H}), 7.71(\mathrm{~m}, 12 \mathrm{H}$, meso$m$ and $p$ - $\mathrm{Ph}-\mathrm{H}), 7.34$ (m, 15H, $\beta$-PE-H). MALDI-TOF MS calcd. for $\mathrm{ZnC}_{68} \mathrm{H}_{40} \mathrm{~N}_{4}$ : 976.254 (found 975.70).

$\mathrm{H}_{2} \mathrm{TPP}\left(2^{\prime} \text {-thienyl }\right)_{3}$ was prepared in $66 \%$ yield using $(\mathrm{Bu})_{3} \mathrm{Sn}(2$-thienyl) reagent by Stille coupling reaction as in the synthesis of $\mathrm{H}_{2} \mathrm{TPP}(\mathrm{PE})_{3} \cdot \mathbf{H}_{2} \mathbf{T P P}\left(\mathbf{2}^{\prime}\right.$ thienyl $)_{3}:{ }^{1} \mathrm{H} \mathrm{NMR}$ in $\mathrm{CDCl}_{3}: 8.70(\mathrm{~d}, 1 \mathrm{H}, J=5.2$ $\mathrm{Hz}, \beta$-pyrrole-H), 8.65 (s, 1H, $\beta$-pyrrole-H), 8.61 (d, $1 \mathrm{H}, J=5.4 \mathrm{~Hz}, \beta$-pyrrole- $\mathrm{H}), 8.57(\mathrm{~d}, 1 \mathrm{H}, J=$ $5.2 \mathrm{~Hz}, \beta$-pyrrole-H), $8.53(\mathrm{~d}, 1 \mathrm{H}, J=5.2 \mathrm{~Hz}$, $\beta$-pyrrole-H), 8.28 (m, 2H, meso-o-Ph-H), 8.09 (m, 2H, meso-o-Ph-H), 7.97 (m, 4H, meso-o- $\mathrm{Ph}-\mathrm{H}), 7.75$ $(\mathrm{m}, 3 \mathrm{H}$, meso-m \& p-Ph-H), $7.37(\mathrm{~m}, 9 \mathrm{H}$, meso-m $\& p-\mathrm{Ph}-\mathrm{H}), 7.13(\mathrm{dd}, 1 \mathrm{H}, J=5.13 \mathrm{~Hz}$, thienyl$\mathrm{H}), 6.98(\mathrm{~m}, 1 \mathrm{H}$, thienyl-H), $6.73(\mathrm{~m}, 1 \mathrm{H}$, thienyl$\mathrm{H}), 6.60(\mathrm{~m}, 6 \mathrm{H}$, thienyl-H). $-2.20(\mathrm{~s}, 2 \mathrm{H}, \mathrm{NH}) . \mathrm{HR}$ ESI-MS calcd. for $\mathrm{C}_{56} \mathrm{H}_{37} \mathrm{~N}_{4} \mathrm{~S}_{3}[\mathrm{M}+\mathrm{H}]^{+}: 861.2180$ (found 861.2194). CuTPP( $\left(\mathbf{2}^{\prime} \text {-thienyl }\right)_{3}$ : MALDI-TOF MS calcd. for $\mathrm{CuC}_{56} \mathrm{H}_{34} \mathrm{~N}_{4} \mathrm{~S}_{3}$ : 921.124 (found: 921.52). ZnTPP(2'-thienyl) $)_{3}$ : ${ }^{1} \mathrm{H}$ NMR $(400 \mathrm{MHz})$ in $\mathrm{CDCl}_{3}$ : 8.89 (s,1H, $\beta$-pyrrole-H), 8.79 (d, $2 \mathrm{H}, \mathrm{J}=7.2 \mathrm{~Hz}, \beta$ pyrrole-H $), 8.66(\mathrm{~m}, 2 \mathrm{H}, \beta$-pyrrole- $\mathrm{H}), 8.57(\mathrm{~d}, 2 \mathrm{H}$, $J=7.4 \mathrm{~Hz}$, meso-o-Ph-H), $8.21(\mathrm{~m}, 2 \mathrm{H}$, meso-o-Ph$\mathrm{H}), 7.95$ (m, 4H, meso-o-Ph-H), 7.86 (m, 2H, meso-m \& $p-\mathrm{Ph}-\mathrm{H}), 7.72(\mathrm{~m}, 4 \mathrm{H}$, meso-m \& p-Ph- $\mathrm{H}), 7.34(\mathrm{~m}$, $6 \mathrm{H}, m$ \& $p-\mathrm{Ph}-\mathrm{H}), 7.18(\mathrm{~m}, 1 \mathrm{H}$, thienyl-H), $7.04(\mathrm{~m}$, $1 \mathrm{H}$, thienyl-H), $6.76(\mathrm{~m}, 1 \mathrm{H}$, thienyl- $\mathrm{H}), 6.60(\mathrm{~m}, 6 \mathrm{H}$, 
thienyl-H). MALDI-TOF MS calcd. for $\mathrm{ZnC}_{56} \mathrm{H}_{34} \mathrm{~N}_{4} \mathrm{~S}_{3}$ : 924.50 (found: 924.61).

\subsection{Synthesis of 2,5,10,12,15,20-hexaphenylpor- phyrin, $\mathrm{H}_{2} \mathrm{TPP}(\mathrm{Ph})_{2}$ and its zinc(II) complex}

The Suzuki cross-coupling reaction of $\mathrm{H}_{2} \mathrm{TPPBr}_{2}$ with five equivalent of phenylboronic acid was carried out using the reported procedure. ${ }^{20} \mathrm{H}_{2} \mathrm{TPP}(\mathrm{Ph})_{2}$ was isolated in $71 \%$ yield. The product was obtained as a single major fraction along with the $10-15 \%$ of other minor mixture of phenylated products. ${ }^{1} \mathrm{H}$ NMR in $\mathrm{CDCl}_{3}$ : 8.73 (s, $1 \mathrm{H}, \beta$-pyrrole- $\mathrm{H}), 8.70$ (s, $2 \mathrm{H}, \beta$-pyrrole- $\mathrm{H}$ ), $8.64(\mathrm{~d}, 1 \mathrm{H}, J=7.5 \mathrm{~Hz}, \beta$-pyrrole-H), $8.60(\mathrm{~d}, 1 \mathrm{H}$, $J=7.5 \mathrm{~Hz}, \beta$-pyrrole-H), 8.49 (s, $1 \mathrm{H}, \beta$-pyrrole-H), $8.19(\mathrm{~m}, 4 \mathrm{H}$, meso-o- $\mathrm{Ph}-\mathrm{H}), 7.86(\mathrm{~m}, 4 \mathrm{H}$, meso-o- $\mathrm{Ph}-$ $\mathrm{H}), 7.76(\mathrm{~m}, 6 \mathrm{H}$, meso-m \& $p-\mathrm{Ph}-\mathrm{H}), 7.31(\mathrm{~m}, 6 \mathrm{H}$, meso-m \& p-Ph-H), $7.19(\mathrm{~m}, 4 \mathrm{H}, \beta-\mathrm{Ph}-\mathrm{H}), 7.09(\mathrm{~m}$, $6 \mathrm{H}, \beta-\mathrm{Ph}-\mathrm{H}),-2.43$ (s, $1 \mathrm{H}, \mathrm{NH}),-2.53$ (s, 1H, NH). ${ }^{13} \mathrm{C} \mathrm{NMR}$ in $\mathrm{CDCl}_{3}: 142.7,142.2,140.5,140.2,138.3$, $136.1,135.8,134.7,134.6,134.5,130.3,127.7,127.3$, 127.2, 127.1, 126.8, 126.7, 126.6, 126.1, 125.8, 125.8, 121.5, 121.1, 119.9, 119.6. HR ESI-MS calcd. for $\mathrm{C}_{56} \mathrm{H}_{38} \mathrm{~N}_{4}[\mathrm{M}+\mathrm{H}]^{+}: 767.3176$ (found 767.3175). Elemental analysis calcd. for $\mathrm{C}_{56} \mathrm{H}_{38} \mathrm{~N}_{4} \cdot 0.5 \mathrm{H}_{2} \mathrm{O}: \mathrm{C}, 86.68$; H, 5.07; N, 7.22\%. Found: C, 86.26; H, 4.57; N, 7.05\%. $\operatorname{ZnTPP}(\mathbf{P h})_{2}:{ }^{1} \mathrm{H}$ NMR in $\mathrm{CDCl}_{3}: 8.89(\mathrm{~s}, 1 \mathrm{H}, \beta$ pyrrole-H), $8.81(\mathrm{~m}, 3 \mathrm{H}, \beta$-pyrrole- $\mathrm{H}), 8.77(\mathrm{~d}, 1 \mathrm{H}$, $\beta$-pyrrole-H), 8.67 (s, 1H, $\beta$-pyrrole- $\mathrm{H}), 8.23$ (m, 4H, meso-o-Ph-H), 7.87 (m, 4H, meso-o- $\mathrm{Ph}-\mathrm{H}), 7.70(\mathrm{~m}$, $6 \mathrm{H}$, meso- $m$ and $p$ - $\mathrm{Ph}-\mathrm{H}), 7.35(\mathrm{~m}, 4 \mathrm{H}$, meso- $m$ and $p$ $\mathrm{Ph}-\mathrm{H}), 7.20$ (m, 4H, $\beta$-Ph-H), 7.13 (m, 6H, $\beta$-Ph-H). HR ESI-MS calcd. for $\mathrm{ZnC}_{56} \mathrm{H}_{36} \mathrm{~N}_{4}[\mathrm{M}+\mathrm{H}]^{+}: 829.2310$ (found 829.2325).

\section{Results and Discussion}

\subsection{Synthesis and characterisation}

A mixture of antipodal $\mathrm{H}_{2} \mathrm{TPPBr}$ and $\mathrm{H}_{2} \mathrm{TPPBr}_{3}$ were prepared in moderate yields of $30 \%$ and $40 \%$ respectively, using controlled amount of $\mathrm{N}$-bromosuccinimide (2.8 equivalent) with $\mathrm{H}_{2}$ TPP in $\mathrm{CHCl}_{3}$ at an ambient temperature using the reported procedure. ${ }^{22} \mathrm{~A}$ direct synthesis of $\mathrm{MTPPR}_{3}\left(\mathrm{R}=\mathrm{CH}_{3}, \mathrm{Ph}, 2\right.$ thienyl and $\mathrm{PE}$ ) from $\mathrm{H}_{2} \mathrm{TPPBr}_{3}$ was achieved using appropriate $\mathrm{C}-\mathrm{C}$ coupling reaction. The Suzuki crosscoupling reaction of $\mathrm{H}_{2} \mathrm{TPPBr}_{3}$ with methylboronic acid and phenylboronic acid was carried out using slightly modified procedure ${ }^{20}$ which yielded corresponding $\mathrm{H}_{2} \mathrm{TPP}\left(\mathrm{CH}_{3}\right)_{3}$ and $\mathrm{H}_{2} \mathrm{TPP}(\mathrm{Ph})_{3}$ in $45 \%$ and $85 \%$, respectively. Previous synthesis of $\mathrm{H}_{2} \mathrm{TPP}\left(\mathrm{CH}_{3}\right)_{3}$ was reported using Heck reaction of $\mathrm{H}_{2} \mathrm{TPPBr}_{4}{ }^{42} \mathrm{Sim}$ ilarly, synthesis of $\mathrm{H}_{2} \mathrm{TPP}(2$-thienyl) 3 was reported as a minor side product of the Stille coupling reaction of $\mathrm{H}_{2} \mathrm{TPPBr}_{4}$ with $(\mathrm{Bu})_{3} \mathrm{Sn}\left(2\right.$-thienyl). ${ }^{21}$ Here the $\mathrm{H}_{2} \mathrm{TPP}(\mathrm{PE})_{3}$ (yield, 77\%) and $\mathrm{H}_{2} \mathrm{TPP}(2$-thienyl) (yield, 66\%) were selectively prepared by Stille coupling reaction of $(\mathrm{Bu})_{3} \mathrm{Sn}(\mathrm{R})(\mathrm{R}=\mathrm{PE}$ and 2-thienyl) with $\mathrm{H}_{2} \mathrm{TPPBr}_{3}$ as the precursor using modified reported procedure. ${ }^{21}$ The corresponding metal $(\mathrm{Cu}$ (II) and $\mathrm{Zn}(\mathrm{II}))$ complexes of $\operatorname{MTPP}(\mathrm{X})_{4} \mathrm{~s}$ were isolated in almost quantitative yields using conventional procedures. The Suzuki cross-coupling reaction of dibromo$\mathrm{H}_{2}$ TPP with phenylboronic acid yielded mostly one isomer 2,5,10,12,15,20-hexaphenylporphyrin as the product. Its $\mathrm{Zn}$ (II)-complex was prepared by conventional procedures. All the synthesised porphyrins were characterized by electronic absorption, ${ }^{1} \mathrm{H}$ NMR spectroscopy and mass spectrometry.

Electronic absorption spectra of $\mathrm{H}_{2} \mathrm{TPPBr}_{3}$ and its Stille coupled product, $\mathrm{H}_{2} \mathrm{TPP}(\mathrm{PE})_{3}$ are shown in figure 2. The absorption spectral data of all the synthesised porphyrins are listed in table 1. For comparison, the data of $\mathrm{H}_{2} \mathrm{TPPBr}$ are also listed in the table 1 . Generally, all the free-base derivatives showed a 'B' band and four visible ' $Q$ ' bands. Among the porphyrins examined, $\mathrm{H}_{2} \mathrm{TPP}(\mathrm{PE})_{3}$ showed the highest red-shift in both $\mathrm{B}$ and $\mathrm{Q}$ bands relative to other free-base porphyrins. The magnitude of the red-shift in longest wavelength $\left(\mathrm{Q}_{\mathrm{x}}(0,0)\right)$ is $\sim 12 \mathrm{~nm}$ and $\mathrm{B}$ band is $\sim 8 \mathrm{~nm}$ per PE group relative to $\mathrm{H}_{2} \mathrm{TPP}\left(\mathrm{CH}_{3}\right)_{3}$. This is possibly due to conjugation of $\mathrm{PE}$ groups with the porphyrin $\pi$-system. Similar behaviour was reported for $\mathrm{H}_{2} \mathrm{TPP}(\mathrm{CHO})(\mathrm{PE})_{2}{ }^{25}$ and $\mathrm{H}_{2} \mathrm{TPP}(\mathrm{PE})_{8}{ }^{27}$ derivatives.

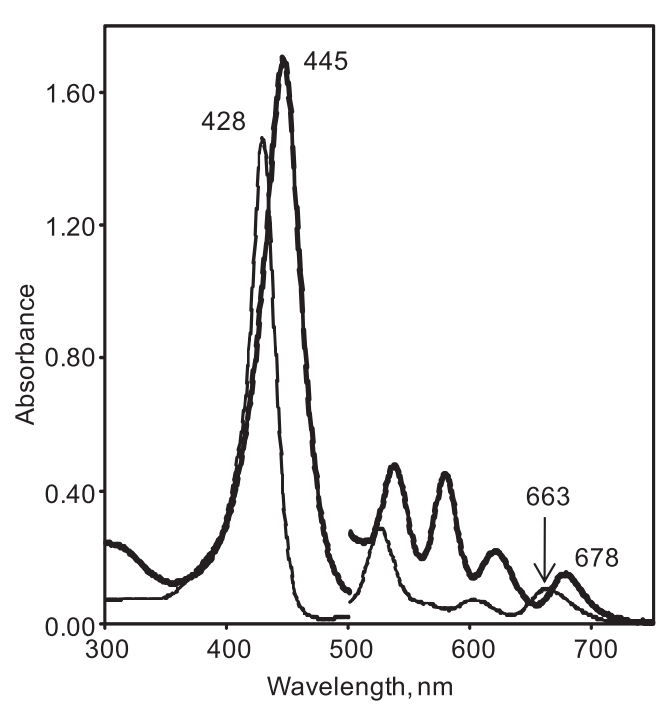

Figure 2. Optical absorption spectra of $\mathrm{H}_{2} \mathrm{TPP}(\mathrm{PE})_{3}$ (heavy line) and $\mathrm{H}_{2} \mathrm{TPPBr}_{3}$ (thin line) in $\mathrm{CH}_{2} \mathrm{Cl}_{2}$ at $298 \mathrm{~K}$. The intensity of $\mathrm{Q}$ bands are magnified by three times. 
Table 1. Electronic absorption spectral data ${ }^{\mathrm{a}}$ of $\mathrm{H}_{2} \mathrm{TPP}(\mathrm{R})_{3}$ and their metal complexes in $\mathrm{CH}_{2} \mathrm{Cl}_{2}$ at $298 \mathrm{~K}$.

\begin{tabular}{lcc}
\hline Porphyrin & B band, nm & Q bands, nm \\
\hline $\mathrm{H}_{2} \mathrm{TPPBr}_{3}$ & $428(5.44)$ & $525(4.27), 602(3.57), 663(3.75)$ \\
& & \\
$\mathrm{H}_{2} \mathrm{TPP}\left(\mathrm{CH}_{3}\right)_{3}$ & $333(4.36), 419$ & $518(4.31), 547(\mathrm{sh}), 587(3.84)$, \\
& $(5.59)$ & $641(3.66)$ \\
$\mathrm{H}_{2} \mathrm{TPP}(\mathrm{Ph})_{3}$ & $429(5.42)$ & $525(4.19), 561(3.85), 598(3.75)$, \\
& & $662(3.45)$ \\
$\mathrm{H}_{2} \mathrm{TPP}\left(2^{\prime} \text {-thienyl }\right)_{3}$ & $436(5.30)$ & $532(4.24), 564(\mathrm{sh}), 607(3.70)$, \\
& & $680(3.66)$ \\
$\mathrm{H}_{2} \mathrm{TPP}(\mathrm{PE})_{3}$ & $445(5.34)$ & $537(4.32), 579(4.29), 620(3.96)$, \\
& & $678(3.81)$ \\
$\mathrm{H}_{2} \mathrm{TPP}(\mathrm{Ph})_{2}$ & $425(5.47)$ & $522(4.25), 557(3.90), 596(3.78)$, \\
& & $652(3.51)$ \\
$\left.\mathrm{CuTPP}(\mathrm{CH})_{3}\right)_{3}$ & $417(5.53)$, & $541(4.20), 575(\mathrm{sh})$ \\
$\mathrm{CuTPP}(\mathrm{Ph})_{3}$ & $425(5.54)$ & $549(4.30), 584(\mathrm{sh})$ \\
$\mathrm{CuTPP}\left(2^{\prime}-\text { thienyl }\right)_{3}$ & $429(5.45)$ & $556(4.31), 592(4.02)$ \\
$\mathrm{CuTPP}(\mathrm{PE})_{3}$ & $445(5.41)$ & $531(3.98), 565(4.32), 611(4.51)$ \\
$\mathrm{ZnTPP}(\mathrm{CH})_{3}$ & $345(4.24), 420(5.67)$ & $549(4.30), 581(\mathrm{sh})$ \\
$\mathrm{ZnTPP}(\mathrm{Ph})_{3}$ & $355(4.23), 428(5.49)$ & $555(4.23), 601(\mathrm{sh})$ \\
$\mathrm{ZnTPP}\left(2^{\prime}-\text { thienyl }\right)_{3}$ & $435(5.46)$ & $561(4.30), 597(3.93)$ \\
$\mathrm{ZnTPP}(\mathrm{PE})_{3}$ & $450(5.44)$ & $536(3.98), 573(4.32), 617(4.51)$ \\
$\mathrm{ZnTPP}(\mathrm{Ph})_{2}^{\mathrm{b}}$ & $426(100)$ & $553(6.0), 590(\mathrm{sh})$ \\
\hline
\end{tabular}

${ }^{a}$ values in parentheses refers to $\log \varepsilon$

${ }^{b}$ values in parentheses indicates normalized absorbance.

Interestingly, the extent of red-shift in both ' $\mathrm{B}$ ' and longest wavelength $\left(\mathrm{Q}_{\mathrm{x}}(0,0)\right)$ band in $\mathrm{H}_{2} \mathrm{TPP}(\mathrm{X})_{3} \mathrm{~s}$ depend on the nature of the substituent ' $\mathrm{X}$ ' and follow the general trend: $\mathrm{CH}_{3}<\mathrm{Ph} \sim \mathrm{Br}<2$-thienyl $<$ PE. Moreover, the red-shift of the ' $\mathrm{B}$ ' and ' $\mathrm{Q}$ ' bands increase with an increase in the number of phenyl, thienyl, $\mathrm{CH}_{3}$ and $\mathrm{PE}$ groups. The metal complexes revealed a decrease in the number of absorption bands relative to their free-base porphyrins. ${ }^{43}$ All the free-base porphyrins and their metal complexes exhibited comparable molar absorption coefficients relative to their corresponding $\operatorname{MTPP}(\mathrm{X})_{4}\left(\mathrm{X}=\mathrm{CH}_{3}, \mathrm{Br}\right.$, 2-thienyl and $\mathrm{Ph}$ ) derivatives. ${ }^{16,21,30}$

A comparison of ${ }^{1} \mathrm{H}$ NMR data of $\mathrm{H}_{2} \mathrm{TPPX}_{3}$ with other substituted porphyrins showed interesting features. $\mathrm{H}_{2} \mathrm{TPP}\left(\mathrm{CH}_{3}\right)_{3}$ feature two independent singlets at $2.45 \mathrm{ppm}$ (6 protons) and $2.60 \mathrm{ppm}$ (3 protons) for $\mathrm{CH}_{3}$ groups while a singlet at $2.39 \mathrm{ppm}$ was reported for $\mathrm{H}_{2} \mathrm{TPP}\left(\mathrm{CH}_{3}\right)_{4}$ in $\mathrm{CDCl}_{3}$. ${ }^{44}$ It is of interest to note that the proton adjacent to ' $\mathrm{X}$ ' in one of the $\beta$-pyrrole show a downfielded resonance for $\mathrm{X}=2$-thienyl or $\mathrm{PE}$ while it was an upfield signal for $\mathrm{X}=\mathrm{CH}_{3}$ or $\mathrm{Ph}$. The imino protons in $\mathrm{H}_{2} \mathrm{TPP}\left(\mathrm{CH}_{3}\right)_{3}$ showed two singlets $(-2.67 \mathrm{ppm}$ and $-2.94 \mathrm{ppm})$ while only one singlet was reported for $\mathrm{H}_{2} \mathrm{TPP}(\mathrm{Ph})_{3}(-2.23 \mathrm{ppm}), \mathrm{H}_{2} \mathrm{TPP}(2-$ thienyl $)_{3}(-2.21 \mathrm{ppm})$ and $\mathrm{H}_{2} \mathrm{TPP}(\mathrm{PE})_{3}(-2.64 \mathrm{ppm})$ derivatives. The observed ${ }^{1} \mathrm{H}$ NMR spectral data is consistent with the reported $\mathrm{H}_{2} \mathrm{TPP}(\mathrm{X})_{3}\left(\mathrm{X}=\mathrm{CH}_{3}, \mathrm{Ph}\right.$ and 2-thienyl) derivatives. ${ }^{21,22,42} \mathrm{Zn}$ (II)-porphyrins featured slightly down-fielded resonances relative to their corresponding free base porphyrins. ${ }^{44}$

$\operatorname{MTPP}(\mathrm{Ph})_{2}(\mathrm{M}=2 \mathrm{H}$, and $\mathrm{Zn}(\mathrm{II}))$ showed blueshifted electronic absorption bands relative to the corresponding $\operatorname{MTPP}(\mathrm{R})_{3}$ derivatives (table 1 ). ${ }^{1} \mathrm{H}$ NMR of $\mathrm{H}_{2} \mathrm{TPP}(\mathrm{Ph})_{2}$ shows less number of downfielded proton resonances relative to $\mathrm{H}_{2} \mathrm{TPP}(\mathrm{Ph})_{3}$ in $\mathrm{CDCl}_{3}$ at $298 \mathrm{~K}$. The $\mathrm{H}_{2} \mathrm{TPP}(\mathrm{Ph})_{2}$ shows proton resonances of the phenyls upto $7.07 \mathrm{ppm}$ while $\mathrm{H}_{2} \mathrm{TPP}(\mathrm{Ph})_{3}$ shows resonances upfielded to a value of $6.8 \mathrm{ppm}$. Imino protons of $\mathrm{H}_{2} \mathrm{TPP}(\mathrm{Ph})_{3}$ and $\mathrm{H}_{2} \mathrm{TPP}(\mathrm{Ph})_{2}$ appear as one singlet and two singlets, respectively. The complexity of the proton resonances are more for the phenyls in $\mathrm{H}_{2} \mathrm{TPP}(\mathrm{Ph})_{3}$ relative to $\mathrm{H}_{2} \mathrm{TPP}(\mathrm{Ph})_{2}$ and this is perhaps due to the decrease in symmetry of the former than the latter. The $\mathrm{ZnTPP}(\mathrm{Ph})_{2}$ shows marginal change in ${ }^{1} \mathrm{H}$ NMR relative to its free base porphyrin. ${ }^{1} \mathrm{H}$ NMR spectra of $\mathrm{H}_{2} \mathrm{TPP}(\mathrm{X})_{4}\left(\mathrm{X}=\mathrm{Ph}, \mathrm{Br}\right.$ and $\left.\mathrm{CH}_{3}\right)$ derivatives exhibited singlet for the antipodal $\beta$-pyrrole protons. ${ }^{16,30,42}$

\subsection{Crystal structure of $\mathrm{ZnTPP}(\mathrm{Ph})_{2}(\mathrm{Py})_{2}, 1$ complex}

To determine the distribution of the two phenyl groups at the $\beta$-pyrrole positions of the $\mathrm{ZnTPP}(\mathrm{Ph})_{2}$, its structure 1 was determined by single crystal XRD analysis. Crystallographic data of the complex, $\mathbf{1}$ is listed in 
Table 2. Crystallographic data of $\mathrm{ZnTPP}(\mathrm{Ph})_{2}(\mathrm{Py})_{2}, \mathbf{1}$.

\begin{tabular}{lc}
\hline Structure & $\mathbf{1}$ \\
\hline Chemical formula & $\mathrm{C}_{66} \mathrm{H}_{46} \mathrm{~N}_{6} \mathrm{Zn}$ \\
Formula weight & 988.46 \\
Crystal system & $\mathrm{P}-1$ \\
Space group & Triclinic \\
$\mathrm{a}(\AA)$ & $9.6100(19)$ \\
$\mathrm{b}(\AA)$ & $11.400(2)$ \\
$\mathrm{c}(\AA)$ & $11.750(2)$ \\
$\alpha\left({ }^{\circ}\right)$ & $93.51(3)$ \\
$\beta\left({ }^{\circ}\right)$ & $103.50(3)$ \\
$\gamma\left({ }^{\circ}\right)$ & $96.66(3)$ \\
Volume $\left(\AA^{3}\right)$ & $1238.0(4)$ \\
$\mathrm{Z}$ & 1 \\
$\mathrm{D}_{\text {calcd. }}\left(\mathrm{g} / \mathrm{cm}^{3}\right)$ & 1.326 \\
$\mathrm{~F} 000$ & 514 \\
$\mathrm{Crystal}$ size $\left.(\mathrm{mm})^{3}\right)$ & $0.29 \times 0.24 \times 0.20$ \\
$\theta$ range $\left({ }^{\circ}\right)$ & $2.23-26.43$ \\
Reflections collected & 13445 \\
Independent reflections & 4239 \\
$\mathrm{GOF}$ on $\mathrm{F}^{2}$ & 0.997 \\
$\mathrm{R}_{1}[I>2 \sigma(I)]$ & 0.0865 \\
$w \mathrm{R}_{2}[I>2 \sigma(I)]$ & 0.2315 \\
Residual $^{\circ}\left(\mathrm{e} \AA^{-3}\right)$ & $-0.723-1.159$ \\
\hline
\end{tabular}

table 2 . The molecule crystallizes in triclinic P-1 with half the porphyrin unit and a coordinated pyridine in the asymmetric unit. The unit cell has one porphyrin unit $(Z=1)$. Molecular structure of the complex is shown in figure 3. It can be seen that the $\mathrm{Zn}$ (II)-centre shows unusual six-coordination geometry having two axially coordinated pyridines with planar macrocycle. The stereochemistry of the 24-atom core is comparable to six-coordinated $\mathrm{ZnTPP}(\mathrm{THF})_{2}$ complex. $^{45}$

The structure $\mathbf{1}$ is compared with the reported sixcoordinated ZnTPP(THF $)_{2},{ }^{45} \mathbf{2}$ to determine the influence of coordination and porphyrin macrocycle on the

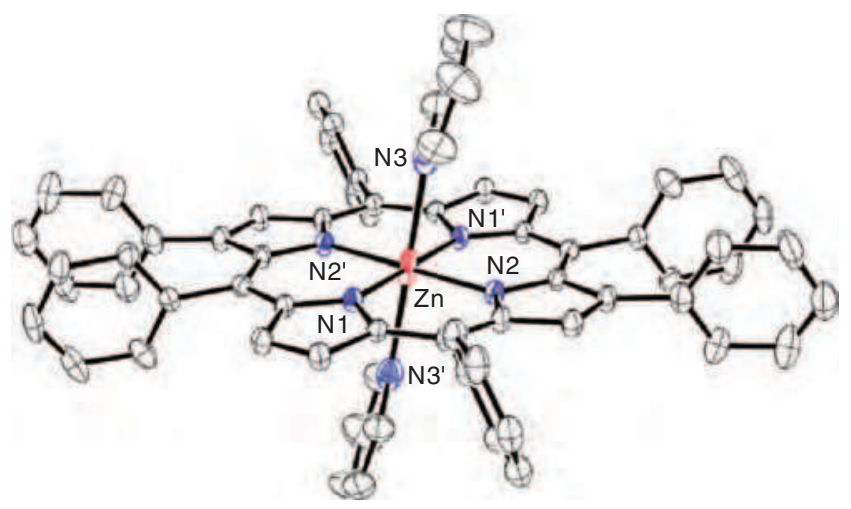

Figure 3. ORTEP of $\mathrm{ZnTPP}(\mathrm{Ph})_{2}(\mathrm{Py})_{2}$ complex (thermal ellipsoids at $30 \%$ probability level). Hydrogens are not shown for clarity. Selected atoms are labelled for clarity. Colour scheme: C, black; N, blue and Zn, red.
Table 3. Some selected mean bond lengths and geometrical parameters of six-coordinated $\mathrm{Zn}$ (II)-porphyrin structures.

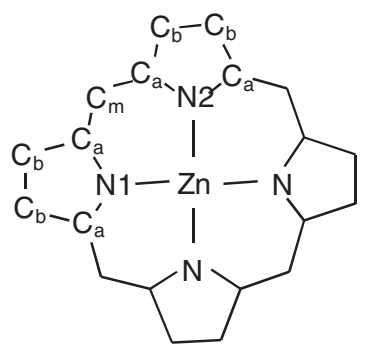

$\mathrm{ZnTPP}(\mathrm{Ph})_{2}(\mathrm{Py})_{2}, \mathbf{Z} \quad \mathrm{ZnTPP}(\mathrm{THF})_{2}^{\mathrm{a}} 2$

$\begin{array}{lcc}\text { Bond distance }(\AA) & & \\ \mathrm{Zn}-\mathrm{N} & 2.055(6) & 2.057(1) \\ \mathrm{Zn}-\mathrm{X}_{\text {axial }} & 2.459(5) & 2.380((2) \\ \mathrm{C}_{\mathrm{b}}-\mathrm{C}_{\mathrm{b}} & 1.355(9) & 1.349(3) \\ \mathrm{N}-\mathrm{C}_{\mathrm{a}} & 1.377(9) & 1.371(3) \\ \mathrm{C}_{\mathrm{a}}-\mathrm{C}_{\mathrm{m}} & 1.397(8) & 1.403(4) \\ \text { Angle }\left({ }^{\circ}\right) & & \\ \mathrm{C}_{\mathrm{a}}-\mathrm{N}-\mathrm{C}_{\mathrm{a}} & 106.9(4) & 107.0(2) \\ \mathrm{N}-\mathrm{C}_{\mathrm{a}}-\mathrm{C}_{\mathrm{m}} & 125.3(6) & 125.8(3) \\ \mathrm{N}-\mathrm{C}_{\mathrm{a}}-\mathrm{C}_{\mathrm{b}} & 109.3(6) & 109.3(4) \\ \mathrm{C}_{\mathrm{a}}-\mathrm{C}_{\mathrm{b}}-\mathrm{C}_{\mathrm{b}} & 107.3(5) & 107.2(1) \\ \mathrm{C}_{\mathrm{a}}-\mathrm{C}_{\mathrm{m}}-\mathrm{C}_{\mathrm{a}} & 126.6(6) & 125.0(2) \\ \Delta \mathrm{Zn}(\mathrm{II}),(\AA) & \pm 0.060(3) & - \\ \text { r.m.s. }(\AA) & 0.031(5) & - \\ \text { Mean dihedral angle }\left(^{\circ}\right) & & \\ \text { Meso-phenyl } & 76.4(5) & 63.2 \\ \text { Pyrrole } & 1.9(2) & -\end{array}$

${ }^{a}$ from ref. ${ }^{45} \cdot \Delta(\mathrm{Zn}(\mathrm{II}))$, deviation of $\mathrm{Zn}(\mathrm{II})$ ion from porphyrin mean plane; r.m.s, refers to average deviation of the 24-atoms core from their least-squares plane.

selected mean bond lengths and geometrical parameters in these complexes (table 3$)$. The $\left(\mathrm{Zn}-\mathrm{N}_{\text {por }}\right)_{\mathrm{av}}$ for the substituted pyrrole in $\mathrm{ZnTPP}(\mathrm{Ph})_{2}(\mathrm{Py})_{2}$ is almost similar to ZnTPP(THF $)_{2}$ but marginally longer than fourcoordinated ZnTPP (2.036(6) A). ${ }^{46}$ As anticipated, the axially bonded two pyridine nitrogens are fairly longer $\mathrm{Zn}-\mathrm{N}_{\mathrm{py}}$ in $\mathbf{1}$ than $\mathrm{Zn}-\mathrm{O}_{\text {thf }}$ in 2. Similar distances are reported for the five-coordinated $\mathrm{ZnTPP}(\mathrm{Ph})_{4}(\mathrm{Py})$ complex $(2.239(8) \AA)^{47}$ and other $\mathrm{Zn}(\mathrm{II})$-porphyrins. ${ }^{23,28,48}$ The $\mathrm{Zn}(\mathrm{II})$ is almost in plane with the four nitrogens in $\mathbf{1}$ but they are displaced towards the axial ligand in five coordinated structures. The comparison of selected mean bond lengths of pyrrole and the macrocyclic geometric parameters of $\mathbf{1}$ and $\mathbf{2}$ are quite similar in these structures. These features are also quite comparable to four coordinated ZnTPP structure.

In the case of structure of $\mathbf{1}$, axially coordinated pyridines are in eclipsed configuration relative to each other. Further, the pyridine ring plane is in staggered orientation relative to opposite pyrrolic nitrogens. The angle between the plane of the pyridine ring relative to the porphyrin ring mean plane is $71.4^{\circ}$. Moreover, the 


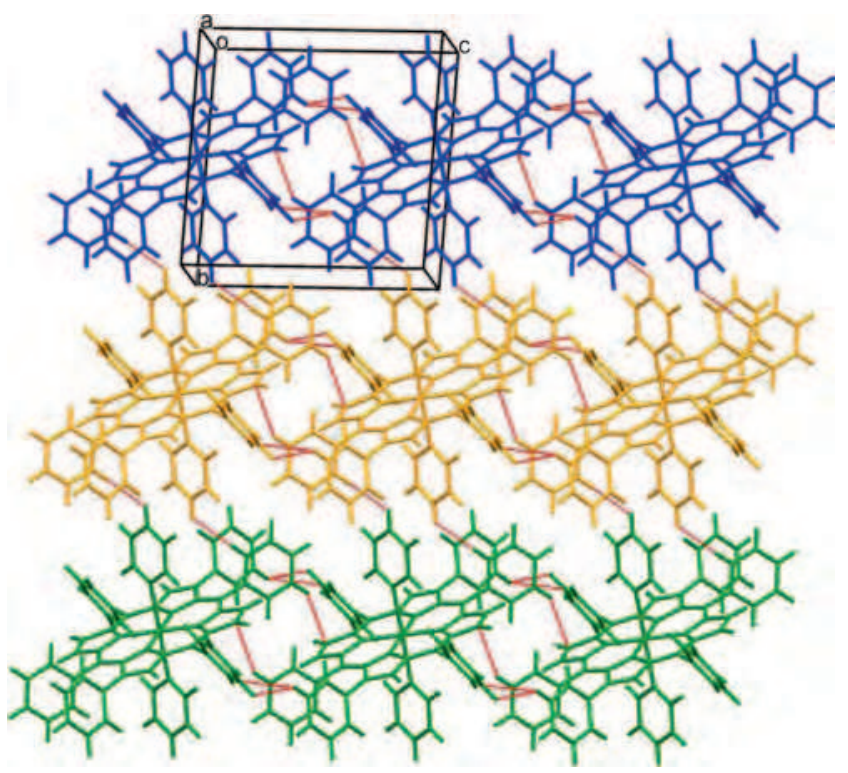

Figure 4. Molecular packing diagram of $\mathbf{1}$ showing the layer-like structure oriented parallel to unit cell 'bc' plane. One-dimensional chains aligned parallel to unit cell 'c' axis are shown in different colours. The inter-porphyrin short contacts are indicated in dotted red lines.

$\mathrm{N}_{\text {py }}$ of the axial pyridines are not exactly perpendicular but $\mathrm{Zn}-\mathrm{N}_{\mathrm{py}}$ makes a tilt angle of $5.6^{\circ}$ relative to the porphyrin mean plane. The mean $\mathrm{N}_{\mathrm{py}} \ldots \mathrm{N}_{\text {por }}$ (pair of nitrogens N1 and N2) distance is shorter (3.082 $\mathrm{A})$ when compard to the distance of $3.321 \AA$ for the nitrogens (N1' and N2') from the opposite side of the porphyrin ring plane (figure 3 ). The pyrrole rings in $\mathbf{1}$ are almost planar within $0.02 \AA$.

The molecular packing may be visualized as onedimensional array of porphyrins oriented along unit cell ' $c$ ' axis. In the array, the interporphyrin interactions ${ }^{49}$ are dominated by weak $\mathrm{C}-\mathrm{H} . \ldots \pi[(\mathrm{Ph}) \mathrm{C}-\mathrm{H} . . \mathrm{C}(\mathrm{Ph})$, $(\mathrm{Ph}) \mathrm{C}-\mathrm{H} . . . \pi(\mathrm{pyr})]$ with short contact distances in the range $2.86-2.89 \AA$ and dihydrogen $(\mathrm{Ph}) \mathrm{H} . . \mathrm{H}(\mathrm{Ph})$ $(2.30 \AA) .{ }^{50,51}$ These one-dimensional arrays are interacting via dihydrogen (H...H) short contacts $(2.30 \AA)$ to form a layer-like structure (figure 4) oriented parallel to unit cell 'bc' plane. Further, layers are held by weak inter-porphyrin $(\mathrm{Ph}) \mathrm{C}-\mathrm{H} . . . \pi(\mathrm{Ph})$ and $(\mathrm{Pyr}) \mathrm{C}-$ $\mathrm{H} . . . \pi(\mathrm{Ph})$ short contacts in the range $2.76-2.83 \AA$ and stack on each other, along the unit cell 'a' axis to form three dimensional packing.

Normal-coordinate structural decomposition analysis ${ }^{52}$ of the macrocycle was performed to delineate the magnitude of in-plane and out-of-plane deformations in $\mathbf{1}$ and it showed essentially very negligible distortion as evidenced from minimum basis set for the out-of-plane displacement, $\mathrm{D}_{\text {oop }}(0.184 \AA)$. The wave $(\operatorname{Eg}(x), 53.6 \%$ and $\operatorname{Eg}(y), 46.1 \%)$ deformations contribute mostly to the distortion of the macrocycle.
Furthermore, a small in-plane displacement $\left(D_{i p}=\right.$ $0.2307 \AA$ ) value was observed with contributions from $\mathrm{B}_{2 \mathrm{~g}}(m-s t r, 4 \%), \mathrm{B}_{1 \mathrm{~g}}(N-s t r, 23.6 \%), \mathrm{A}_{1 \mathrm{~g}}($ bre, $60 \%)$ and $\mathrm{A}_{2 \mathrm{~g}}($ rot, $12.6 \%)$ deformations. Similar trend in distortion of the macrocycle was reported for the planar porphyrin ring in $\mathrm{ZnTPP}(\mathrm{R})_{4}\left(\mathrm{R}=\mathrm{Ph}\right.$ and 2-thienyl). ${ }^{21,47}$

\section{Conclusions}

Synthesis and characterization of some $\beta$-tri-substituted meso-tetraphenylporphyrins and their metal complexes have been reported. The MTPP(PE $)_{3}$ s showed more red-shift in both $\mathrm{B}$ and $\mathrm{Q}$ transitions when compared to other trisubtituted porphyrins examined in this study. The synthesis and crystal structure of the $\operatorname{ZnTPP}(\mathrm{Ph})_{2}$ $(\mathrm{Py})_{2}$ complex was carried out and it revealed six coordination geometry around the $\mathrm{Zn}$ (II) ion. The $\mathrm{Zn}$ (II) ion is situated almost in-plane with the porphyrin ring. The normal-coordinate structural decomposition analysis of 1 shows mainly a very small wave type of deformation of the porphyrin macrocycle.

\section{Acknowledgements}

This work was supported financially by Council of Scientific and Industrial Research (Governemt of India). We thank Mr. Ramkumar, V. for X-ray data collection and department of chemistry for single crystal XRD facility.

\section{References}

1. Kadish K M, Smith K M and Guilard R 2000 In The Porphyrin Handbook (New York: Academic Press:) Vol. 1-10 and references therein

2. Kadish K M, Smith K M and Guilard R (Eds.) 20002013 In Handbook of Porphyrin Science (World Scientific: London) Vol. 1-25 and references therein

3. Shelnutt J A, Song X Z, Ma J G, Jia S L, Jentzen W and Medforth C J 1998 Chem. Soc. Rev. 2731 and references therein

4. Senge M O 2000 In The Porphyrin Handbook Kadish K M, Smith K M and Guilard R (Eds.) (New York: Academic Press) Vol. 1 pp. 239-347 and references therein

5. Chou J H, Kosal M E, Nalwa H S, Rakow N A and Suslick K S 2000 In The Porphyrin Handbook Vol. 6, Kadish K M, Smith K M and Guilard R (Eds.) (New York: Academic Press:) ch. 41 pp 43-131

6. Suslick K S, Bhyrappa P, Chou J H, Kosal M E, Nakagaki S, Smithenry D W and Wilson S R 2005 Acc. Chem. Res. 38283

7. Goldberg I 2002 Cryst. Eng. Comm. 4109

8. Meunier B 1992 Chem. Rev. 921411 
9. Dolphin D, Traylor T G and Xie L Y 1997 Acc. Chem. Res. 30251 and references therein

10. Grinstaff M W, Hill M G, Labinger L A and Gray H B 1994 Science 2641311

11. Senge M O, Fazekas M, Notaras E G A, Blau W J, Zawadzka M, Locos O B and Ni Mhuircheartaigh E M 2007 Adv. Mater. 192737

12. Segura J L, Martin N and Guldi D M 2005 Chem. Soc. Rev. 3421

13. Kadish K M, Royal G, Caemelbecke E V and Gueletti L 2000 In The Porphyrin Handbook Kadish K M, Smith $\mathrm{K} \mathrm{M}$ and Guilard R (Eds) (Academic Press: New York) Vol. 9 Ch. 1, 2-219 and references therein

14. Barkigia K M, Chantranupong L, Smith K M and Fajer J 1988 J. Am. Chem. Soc. 1107566

15. Takeuchi T, Gray H B and Goddard W A 1994 J. Am. Chem. Soc. 1169730

16. Chan K S, Zhou X, Lou B S and Mak T C W 1994 J. Chem. Soc., Chem. Commun. 271

17. Chan K S, Zhou X, Au M T and Tam C Y 1995 Tetrahedron $\mathbf{5 1} 3129$

18. DiMagno M, Lin V S Y and Therein M J $1993 \mathrm{~J}$. Am. Chem. Soc. 1152513

19. DiMagno M and Therein M J 1994 Science 2641105

20. Pan C, Liu M, Zhang L, Wu H, Ding J and Cheng J 2008 Catal. Commun. 9508

21. Bhyrappa P and Velkannan V 2012 Inorg. Chim. Acta 38764

22. Bhyrappa P and Velkannan V 2010 Tetrahedron Lett. 51 40

23. Bhyrappa P, Sarangi U K, Velkannan V and Ramkumar V 2014 Eur. J. Inorg. Chem. 5760

24. Shen D M, Liu C and Chen Q Y 2006 J. Org. Chem. 71 6508

25. Bhyrappa P, Velkannan V and Maity A 2010 J. Porphyrins Phthalocyanines $\mathbf{1 4} 459$

26. Gao G Y, Ruppel J V, Allen D B, Chen Y and Zhang X P 2007 J. Org. Chem. 729060

27. Chandra T, Kraft B J, Huffman J C and Zaleski J M 2003 Inorg. Chem. $\mathbf{4 2} 5158$

28. Terazono Y, Patrick B O and Dolphin D 2002 Inorg. Chem. 416703

29. Crosssley M J and Burn P L 1991 J. Chem. Soc., Chem. Commun. 1569
30. Kumar P K, Bhyrappa P and Varghese B 2003 Tetrahedron Lett. $\mathbf{4 4} 4849$

31. Senge M O, Gerstung V, Ruhlandt-Senge K, Runge S and Lehmann I 1998 J. Chem. Soc., Dalton Trans. 4187

32. Callot H J 1973 Tetrahedron Lett. 504987

33. Callot H J 1974 Bull. Soc. Chim. Fr. 7-8 1492

34. Giraudeau A, Callot H J, Jordan J, Ezhar I and Gross M 1979 J. Am. Chem. Soc. 1013857

35. Hou Q, Zhang Y, Li F, Peng J and Cao Y 2005 Orgnometallics 244509

36. Jaquinod L, Khoury G K, Shea K M and Smith K M 1999 Tetrahedron $\mathbf{5 5} 13151$

37. Adler A D, Longo F R, Finarelli J D, Goldmacher J, Assour J and Korsakoff L 1967 J. Org. Chem. 32476

38. Altomare A G, Cascarano G, Giacovazzo C and Gualardi A 1993 J. Appl. Crystallogr. 26343

39. Sheldrick G M. SHELXL 97, 1997 Program for the Refinement of Crystal Structures (Germany: University of Göettingen)

40. Farrugia L J 1997 J. Appl. Crystallogr. 30565

41. Spek A L 2003 J. Appl. Crystallogr. 367

42. Terazono Y and Dolphin D $2003 \mathrm{~J}$. Org. Chem. 68 1892

43. Gouterman M 1959 J. Chem. Phys. 301139

44. Scheer H and Katz J J 1975 In Porphyrins and Metalloporphyrins Smith K M (Ed.) (Amsterdam: Elsevier)

45. Schauer C K, Anderson O P, Eaton S S and Eaton G R 1985 Inorg. Chem. 244082

46. Scheidt W R, Kastner M E and Hatano K 1978 Inorg. Chem. 17706

47. Bhyrappa P and Karunanithi K 2011 Inorg. Chim. Acta 372417

48. Scheidt W R and Lee Y J 1987 Struct. Bonding (Berlin) 641

49. Desiraju G R and Steiner T 1999 In The weak hydrogen bond in structural chemistry and biology. IUCr Monographs on Crystallography (Oxford University Press)

50. Crabtree R H 1998 Science 2822000

51. Wolstenholme D J and Cameron T S 2006 J. Phys. Chem. A 1198970

52. Sun L, Jentzen $\mathrm{W}$ and Shelnutt J A The NormalCoordinate Structural Decomposition Engine. http:// jasheln.unm.edu/jasheln/content/nsd/NSDengine 